\title{
Pengawasan penggunaan senjata api legal di wilayah hukum Kepolisian Daerah Metro Jaya
}

\author{
Supervision the use of legal weapons in the jurisdiction of Metro \\ Jaya District Police
}

\author{
Nurdianto Eko Wartono \\ Program Studi Magister Kajian Ilmu Kepolisian, Sekolah Pascasarjana \\ Universitas Airlangga \\ Surabaya, 60286, Jawa Timur, Indonesia \\ E-mail: nurdianto.eko.wartono-2015@pasca.unair.ac.id
}

\begin{abstract}
Abstrak
Pada dasarnya setiap orang memiliki hak untuk melindungi diri mereka sendiri dan properti mereka (bela diri) dari ancaman orang lain. Penelitian ini berfokus pada proses perizinan penggunaan senjata api hukum dan upaya polisi untuk mengawasi penggunaan senjata api hukum di yurisdiksi polisi metropolitan regional. Metode dalam penelitian ini adalah kualitatif deskriptif. Hasil penelitian menunjukkan bahwa ada enam jenis izin pemilik senjata api. Upaya polisi dalam mengawasi penggunaan senjata api di kepolisian daerah metropolitan dengan cara semua pemilik senjata api harus lulus persyaratan dan serangkaian tes dari polisi intelijen, melakukan pemeriksaan fisik senjata api atas permintaan perpanjangan izin, teguran untuk pemilik senjata api berlisensi, memberikan sosialisasi terus menerus, dan penyitaan senjata api jika terbukti menjadi pelanggaran. Faktor yang menjadi kendala dalam melaksanakan pengawasan penggunaan senjata api hukum di yurisdiksi polisi metropolitan regional bahwa ada faktor internal dan faktor eksternal. Eksternal internal terkait dengan personil yang terbatas, maksimum sosialisasi, dan berbagai kegiatan di yurisdiksi kepolisian daerah metropolitan. Sementara itu, faktor eksternal yang berkaitan dengan data dari pemilik senjata api sering tidak kompatibel dengan domisili pemilik senjata api tetap sesuai dengan alamat yang tercantum dalam lisensi senjata api dan terkait dengan sifat pribadi dari pemilik senjata api.
\end{abstract}

Kata kunci: pistol senjata; perizinan; polisi; kontrol sosial; kewenangan

\begin{abstract}
Basically everyone has the right to protect themselves and their property (self defense) from the threat of others. The research focuses on the process of licensing the use of legal firearms and the efforts of the police to supervise the use of legal firearms in the jurisdiction of the regional metropolitan police. The method used in this research is descriptive qualitative with supported by interview technique. The result of the research shows that there are six firearms owners permit types. The police effort in supervising the use of legal firearms in the regional metropolitan police by means of all firearms owners must pass the requirement and a series of tests from intelligence police, perform physical check of firearms upon request of extension permit, reprimands to licensed firearms owners, provide continuous socialization, and seizure of firearms if proven to be a violation. Factors that become obstacles in carrying out supervision of the use of legal firearms in the jurisdiction of regional metropolitan police that there are internal factors and external factors. Internal externals related to the limited personnel, maximum socialization, and various of activities in the jurisdiction regional metropolitan police. Meanwhile, external factors related to the data of firearms owners are often incompatible with the domicile of the firearms owner staying in accordance with the address stated in the firearms license and related to the personal nature of the firearms owner.
\end{abstract}

Keywords: gun weapon; licensing; police; social control; authority

\section{Pendahuluan}

Penggunaan senjata api dilakukan oleh pihak-pihak yang berwenang dalam melasanakan tugas atau di bawah izin ketentuan yang berlaku. Awalnya, senjata api hanya dipergunakan untuk kepentingan berperang, akan tetapi kemudian juga dipergunakan untuk kepentingan yang lain, misalnya sebagai salah satu alat atau instrumen utama dalam pembangunan pertahanan melalui penyediaan kelengkapan sarana persenjataan bagi angkatan bersenjata suatu Negara (Bangalore \& Franz 2013), sebagai sarana untuk mendukung tugas-tugas aparat keamanan dalam melakukan pemeliharaan keamanan, ketertiban 
masyarakat dan penegakan hukum sesuai ketentuan peraturan perundang-undangan, sarana kelengkapan tugas satuan pengamanan/polisi khusus, sarana untuk kepentingan olahraga, dan kepentingan pembelaan diri (Yusman 2015; Smith 2001).

Pada dasarnya setiap orang berhak melindungi diri dan hartanya (self defense) dari ancaman pihak lain (Karp 2011). Setiap orang juga memiliki hak untuk hidup sebagaimana tercantum dalam Pasal 9 ayat (1) UU No. 39 Tahun 1999 tentang HAM. Oleh karena itu setiap orang berhak menggunakan berbagai cara dan alat untuk melindungi dirinya termasuk dengan cara menguasai (memiliki/menggunakan) senjata api (Latifah 2017). Atas dasar filosofi hak hidup dan mempertahankan hidup itulah, negara Indonesia membuka kesempatan bagi warga sipil untuk memiliki senjata api dengan melalui syarat dan proses tertentu. Syarat dan proses tersebut tersebar di beberapa peraturan perundang-undangan. Peraturan perundang-undangan yang dimaksud adalah: UU Nomor 8 Tahun 1948 tentang Pendaftaran dan Pemberian Izin Pemakaian Senjata Api; UU No. 12 Tahun 1951 tentang Peraturan Hukuman Istimewa Sementara; UU No. 20 PRP. Tahun 1960 tentang Kewenangan Perizinan Yang Diberikan Menurut Perundang-Undangan Mengenai Senjata Api, Amunisi dan Mesiu; dan UU No. 2 Tahun 2002 tentang Kepolisian Negara Republik Indonesia.

Terkait dengan perizinan, Pasal 9 UU No. 8 Tahun 1948 menentukan bahwa setiap orang yang bukan anggota tentara atau polisi yang memakai dan memiliki senjata api harus mempunyai izin pemakaian senjata api menurut contoh yang ditetapkan oleh Kepala Kepolisian Negara. Dengan demikian Pasal 9 UU No. 8 Tahun 1948 merupakan entry point bagi hak warga sipil untuk memiliki senjata di Indonesia. Warga sipil boleh memiliki senjata api sebagai alat pertahanan diri, tetapi harus sesuai dengan ketentuan dan syarat yang tidak mudah. Oleh sebab itu senjata api bisa digunakan untuk pelindungan diri dari aksi kejahatan (Lott 1998, Hikmawati 2012).

Tabel 1.

Jumlah Rekapitulasi Pelayanan masyarakat (Yansendak) tahun 2015-2017

\begin{tabular}{|c|c|c|c|c|}
\hline \multirow[t]{2}{*}{ Jenis senpi } & \multicolumn{3}{|c|}{ Tahun } & \multirow[t]{2}{*}{ Jumlah } \\
\hline & 2015 & 2016 & 2017 & \\
\hline Rekom bela diri & 1.430 & 2.437 & 2.716 & 6.583 \\
\hline Rekom senpi olahraga & 709 & 819 & 743 & 1.562 \\
\hline Rekom seni satpam/ polsus & 29 & 71 & 49 & 149 \\
\hline Rekom handak & 93 & 81 & 82 & 256 \\
\hline Rekom kembang api & 240 & 177 & 150 & 567 \\
\hline Penguasaan pinjam pakai & 3.081 & 2.307 & 1.671 & 7.059 \\
\hline Jumlah & 5.582 & 5.892 & 5.411 & 16.176 \\
\hline
\end{tabular}

Sumber: Direktorat Intelkam, Polda Metro Jaya, 2017

Pada Tabel 1 dapat dilihat bahwa peredaran senjata api legal di wilayah hukum Polda Metro Jaya tiga tahun terkahir yaitu tahun 2015-2017 mencapai 16.176 pucuk, dari berbagai jenis rekom yang dikeluarkan oleh Polda Metro Jaya. Jika digambarkan, akan terlihat seperti Gambar 1.

Atas dasar regulasi yang telah ditetapkan perundang-undangan, maka peredaran senjata api masih diperbolehkan. Namun, dengan ketentuan tertentu dan pelaksanaan pengawasan terhadap pengguna senjata api legal. Peran negara dalam pengawasan dan pengendalian senjata api mutlak diperlukan karena dalam prakteknya senjata api dimanfaatkan pula untuk melakukan kejahatan sebagaimana tersebut di atas. Negara hadir secara aktif dan efektif di tengah masyarakat guna memastikan warga negaranya aman dari berbagai ancaman dalam bentuk verbal maupun non-verbal. Melalui UndangUndang Nomor 2 Tahun 2002 tentang Kepolisian Negara Republik Indonesia, Pasal 5 ayat (1) menyatakan bahwa kepolisian merupakan lembaga negara yang berperan dalam memelihara keamanan dan ketertiban masyarakat, menegakkan hukum, serta memberikan perlindungan, pengayoman, dan pelayanan kepada masyarakat dalam rangka terpeliharanya keamanan dalam negeri. 


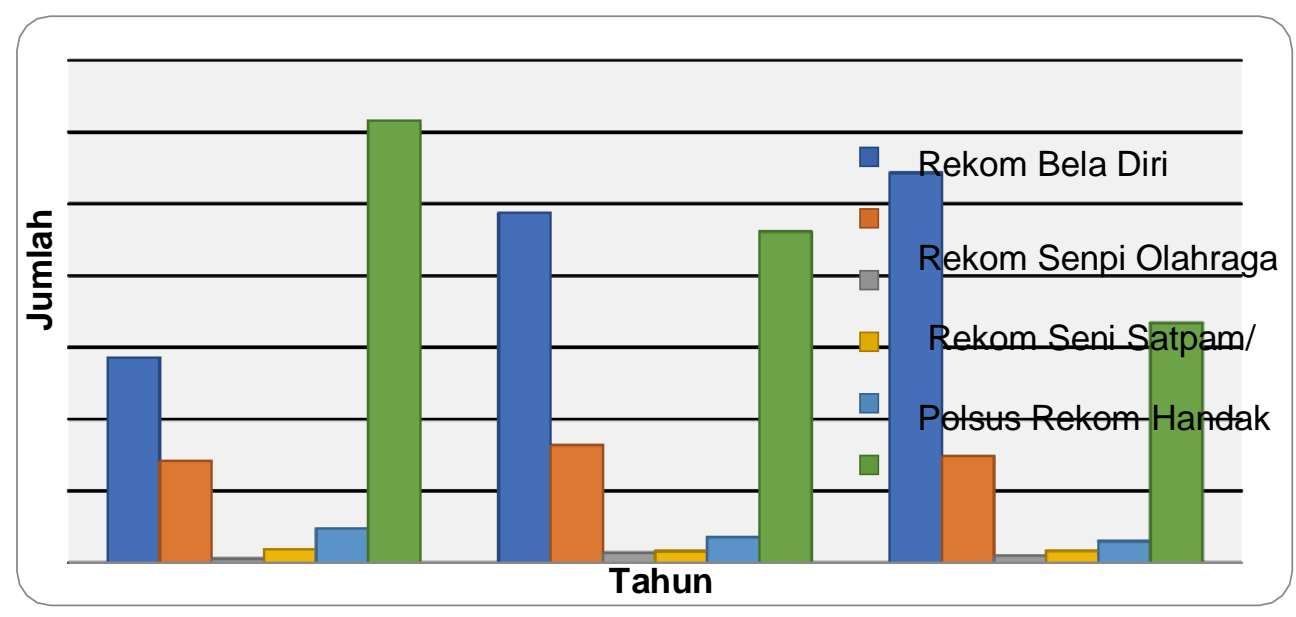

Gambar 1.

Jumlah rekapitulasi pelayanan masyarakat (Yansendak) tahun 2015-2017

Dalam UU tersebut disebuatkan bahwa tugas pokok Kepolisian Negara Republik Indonesia adalah: (a) memelihara keamanan dan ketertiban masyarakat; (b) menegakkan hukum; dan (c) memberikan perlindungan, pengayoman, dan pelayanan kepada masyarakat (Pasal 13 Undang-Undang Nomor 2 Tahun 2002 tentang Kepolisian Negara Republik Indonesia). Dalam melaksanakan tugas pokok sebagaimana dimaksud dalam Pasal 13, Kepolisian Negara Republik Indonesia bertugas salah satunya melakukan penyelidikan dan penyidikan terhadap semua tindak pidana sesuai dengan hukum acara pidana dan peraturan perundang-undangan lainnya.

Penggunaan senjata api memerlukan pengawasan oleh negara yang diatur dalam kepolisian. Menurut Maringan, pengawasan adalah proses dimana pimpinan ingin mengetahui hasil pelaksanaan pekerjaan yang dilakukan bawahan sesuai dengan rencana, perintah, tujuan, kebijakan yang telah ditentukan. Sementara itu Hasibuan \& Malayu (2001) mengemukakan bahwa pengawasan adalah proses penentuan apa yang harus dicapai, yaitu standar, apa yang harus dilakukan yaitu pelaksanaan, menilai pelaksanaan dan apabila perlu melakukan perbaikan-perbaikan, sehingga pelaksanaan sesuai dengan rencana yaitu selaras dan standar.

Menurut George R. Terry mengartikan pengawasan sebagai mendeterminasi apa yang telah dilaksanakan, artinya mengevaluasi prestasi kerja dan apabila perlu, dengan menerapkan tindakantindakan korektif sehingga hasil pekerjaan sesuai dengan rencana yang telah ditetapkan (Terry 2006). Pengawasan menurut Handoko adalah proses untuk menjamin bahwa tujuan tujuan organisasi dan manajemen tercapai dimana hubungan yang sangat erat antara perencanaan dan pengawasan (Handoko 2001). Sementara menurut Siagian, menyebutkan bahwa yang dimaksud dengan pengawasan adalah proses pengamatan daripada pelaksanaan seluruh kegiatan organisasi untuk menjamin agar supaya semua pekerjaan yang sedang dilakukan berjalan sesuai dengan rencana yang telah ditentukan sebelumnya (Siagian 1982).

Senjata api diartikan sebagai setiap alat baik yang sudah terpasang ataupun yang belum, yang dapat dioperasikan atau yang tidak lengkap, yang dirancang atau diubah, atau yang dapat diubah dengan mudah agar mengeluarkan proyektil akibat perkembangan gas-gas yang dihasilkan dari penyalaan bahan yang mudah terbakar didalam alat tersebut, dan termasuk perlengkapan tambahan yang dirancang atau dimaksudkan untuk dipasang pada alat demikian.

Lebih lanjut dijabarkan dalam Instruksi Presiden Republik Indonesia Nomor 9 Tahun 1976 yang menyatakan bahwa senjata api adalah salah satu alat untuk melaksanakan tugas pokok angkatan bersenjata di bidang pertahanan dan keamanan, sedangkan bagi instansi pemerintah di luar angkatan bersenjata, senjata api merupakan alat khusus yang penggunannya diatur melalui ketentuan Instruksi 
Presiden Nomor 9 Tahun 1976, yang menginstruksikan agar para menteri (pimpinan lembaga pemerintah dan non pemerintah) membantu pertahanan dan keamanan agar dapat mencapai sasaran tugasnya.

Dengan demikian, secara tegas telah ditetapkan jika senjata api hanya diperuntukan bagi angkatan bersenjata di bidang pertahanan dan keamanan dalam hal ini TNI dan Polri, sedangkan bagi instansi pemerintah di luar bidang pertahanan dan keamanan penggunaan senjata api diatur dalam Intruksi Presiden Nomor 9 Tahun 1976, yang menginstruksikan agar para menteri (pimpinan lembaga pemerintah dan non-pemerintah) membantu pertahanan dan keamanan agar dapat mencapai sasaran tugasnya.

\section{Metode Penelitian}

Penelitian ini merupakan penelitian yang bersifat deskriptif kualitatif. Penelitian ini dilakukan di wilayah hukum Polda Metro Jaya. Informan penelitian merupakan orang yang memiliki informasi tema atau hal yang diteliti. Adapun informan dalam penelitian ini adalah informan kunci (Direktur Intelkam Polda Metro Jaya) informan utama (anggota kepolisian yang menggunakan senjata api) dan informan tambahan (warga nonmiliter/sipil yang diizinkan menggunakan senjata api).

\section{Hasil dan Pembahasan}

Ada beberapa bentuk perizinan senjata api yang dilayani oleh Polda Metro Jaya, yaitu: Pertama, perizinan impor senjata api. Dalam Peraturan Kepala Kepolisian Negara Republik Indonesia Nomor 8 Tahun 2012 tentang Pengawasan dan Pengendalian Senjata Api Untuk Kepentingan Olahraga Pasal1 angka 10, menjelaskan bahwa pemasukan dari luar negeri (impor) adalah kegiatan memasukan senjata api dan peluru dari luar daerah pabean ke dalam daerah pabean Indonesia. Perizinan impor senjata api di layani oleh Polda Metro Jaya, dengan syarat administratif sebagai berikut: a) hasil cek kredibilitas; b) permohonan bermaterai; c) fotokopi KTP/KTA; d) fotokopi SIUP; e) fotokopi SKCK; f) fotokopi kartu keluarga; g) Pas foto $2 \times 3 \mathrm{~cm}$ sebanyak 2 lembar; h) Pas foto 4x6 cm sebanyak 2 lembar.

Kedua, perizinan hibah. Dalam Peraturan Kepala Kepolisian Negara Republik Indonesia Nomor 8 Tahun 2012 Tentang Pengawasan dan Pengendalian Senjata Api Untuk Kepentingan Olahraga, Pasal 1 angka 15, menjelaskan bahwa penghibahan Senjata Api adalah proses pemindahan hak dan tanggung jawab pemilikan Senjata Api dari seseorang kepada orang lain. Perizinan hibah senjata api dilayani oleh Polda Metro Jaya, dengan syarat administratif sebagai berikut: a) hasil cek kredibilitas; b) permohonan bermaterai; c) surat pernyataan hibah; d) BA. Penitipan Senpi; e) fotokopi KTP/KTA; f) fotokopi kartu keluarga; g) fotokopi kartu senjata; h) fotokopi buku pas; i) fotokopi SIUP; j) fotokopi SKEP jabatan; k) fotokopi SKCK; 1) hasil psikologi; m) surat keterangan sehat; n) surat keterangan menembak; o) Pas foto $2 \times 3 \mathrm{~cm}$ sebanyak 2 lembar; $\mathrm{p}$ ) Pas foto $4 \times 6 \mathrm{~cm}$ sebanyak 2 lembar.

Ketiga, perizinan kepemilikan baru. Dalam Peraturan Kepala Kepolisian Negara Republik Indonesia Nomor 8 Tahun 2012 tentang Pengawasa dan Pengendalian Senjata Api untuk Kepentingan Olahraga, Pasal 1 angka 16, menjelaskan bahwa pemilikan senjata api adalah legalitas dokumen pemilikan senjata api yang mencantumkan identitas pemilik dan Senjata Api dalam bentuk buku. Perizinan pemilikan baru senjata api dilayani oleh Polda Metro Jaya, dengan syarat administratif sebagai berikut: a) hasil cek kredibilitas; b) permohonan bermaterai; c) fotokopi izin impor/asal usul senjata; d) fotokopi KTP/KTA; e) fotokopi kartu keluarga; f) fotokopi SIUP; g) fotokopi SKEP jabatan; h) fotokopi SKCK; i) fotokopi kartu keluarga; j) surat keterangan psikologi; k) surat keterangan sehat; 1) surat keterangan menembak; m) Pas foto $2 \times 3 \mathrm{~cm}$ sebanyak 2 lembar; $\mathrm{n}$ ) Pas foto $4 \times 6 \mathrm{~cm}$ sebanyak 2 lembar.

Keempat, perizinan mutasi. Dalam Peraturan Kepala Kepolisian Negara Republik Indonesia Nomor 8 Tahun 2012 tentang Pengawasan dan Pengendalian Senjata Api untuk Kepentingan Olahraga, Pasal 1 angka 20, yang menjelaskan bahwa pemindahan atau mutasi adalah proses pemindahan senjata api ke domisili atau tempat tinggal baru seseorang yang memiliki izin senjata api. Perizinan mutasi senjata api 
dilayani oleh Polda Metro Jaya, dengan syarat administratif sebagai berikut: a) hasil cek fisik senjata; b) permohonan bermaterai; c) BA penitipan senpi; c) rekomendasi Polda asal senjata; d) fotokopi KTP/KTA; e) fotokopi kartu keluarga; f) fotokopi kartu senjata; g) fotokopi buku pas; h) SKEP jabatan; i) Pas foto $2 \times 3 \mathrm{~cm}$ sebanyak 2 lembar; j) Pas foto $4 \times 6 \mathrm{~cm}$ sebanyak 2 lembar.

Kelima, perizinan perpanjangan kepemilikan. Izin perpanjangan kepemilikan senjata berarti pemohon melakukan perizinan baru setelah masa perizinan senjata api miliknya telah habis masa berlakunya (Grassel et al. 2003). Dalam Peraturan Kepala Kepolisian Negara Republik Indonesia Nomor 8 Tahun 2012 tentang Pengawasan dan Pengendalian Senjata Api untuk Kepentingan Olahraga, Pasal 29 menjelaskan bahwa: (1) Izin pemasukan senjata api olahraga berlaku selama 6 (enam) bulan terhitung sejak tanggal dikeluarkan dan dapat diperpanjang sebanyak 1 (satu) kali untuk jangka waktu 6 (enam) bulan, diajukan paling lambat 1 (satu) bulan sebelum habis masa berlakunya; (2) Izin kepemilikan senjata api (Buku Pas) berlaku selama 5 (lima) tahun terhitung sejak tanggal dikeluarkan, dan wajib didaftar ulang setiap tahun di Polda setempat; (3) Izin penggunaan/membawa senjata api di luar wilayah Polda setempat untuk mengikuti kejuaraan/pertandingan menembak, berlaku selama pertandingan berlangsung; (4) Izin penggunaan/membawa senjata api di luar wilayah Polda setempat untuk kegiatan olahraga berburu, berlaku paling lama 10 (sepuluh) hari dan untuk olahraga safari berburu berlaku paling lama 14 (empat belas) hari; (5) Izin pembelian senjata api berlaku selama waktu 6 (enam) bulan terhitung sejak tanggal dikeluarkan, dan dapat diperpanjang 1 (satu) kali untuk jangka waktu 6 (enam) bulan, dan diajukan paling lambat 1 (satu) bulan sebelum habis masa berlakunya; (6) Izin penghibahan berlaku selama 3 (tiga) bulan terhitung sejak tanggal dikeluarkan, berlaku 1 (satu) kali dan tidak dapat diperpanjang; (7) Izin pemusnahan berlaku selama 6 (enam) bulan terhitung sejak tanggal dikeluarkan, dan dapat diperpanjang untuk jangka waktu 6 (enam) bulan, dan diajukan paling lambat 1 (satu) minggu sebelum habis masa berlakunya; (8) Izin pengangkutan berlaku paling lama 3 (tiga) bulan terhitung sejak tanggal dikeluarkan dan apabila terdapat cukup alasan dapat diperpanjang untuk jangka waktu tertentu; (9) Izin penggunaan pistol angin (air pistol) dan senapan angin (air rifle) dan airsoft gun berlaku selama 1 (satu) tahun terhitung sejak tanggal dikeluarkan dan dapat diperpanjang tiap tahun; (10) Izin gudang senjata api untuk gudang PB Perbakin atau gudang Pengprov Perbakin berlaku selama 3 (tiga) tahun terhitung sejak tanggal dikeluarkan.

Perizinan perpanjangan senjata api dilayani oleh Polda Metro Jaya, dengan syarat administratif sebagai berikut: a) hasil cek fisik senjata; b) permohonan Bermaterai; c) BA penitipan senjata api; d) fotokopi KTP/KTA; e) fotokopi kartu senjata; f) fotokopi buku pas; g) fotokopi kartu keluarga; h) SKEP jabatan; i) Pas fhoto $2 \times 3$ sebanyak 2 lembar; j) Pas fhoto 4x6 sebanyak 2 lembar.

Perizinan Pembaharuan Buku Pemilikan Senjata Api dalam Peraturan Kepala Kepolisian Negara Republik Indonesia Nomor 8 Tahun 2012 tentang Pengawasan dan Pengendalian Senjata Api untuk Kepentingan Olahraga, Pasal 1 angka 17 menjelaskan adanya pembaharuan. Buku Pemilikan Senjata Api adalah pergantian Buku Pemilikan Senjata Api karena habis masa berlakunya baik rusak maupun hilang. Perizinan pembaharuan buku pemilikan senjata api di layani oleh Polda Metro Jaya, dengan syarat administrative sebagai berikut: a) permohonan bermaterai; b) fotokopi KTP/KTA; c) fotokopi kartu senjata; d) Pas foto 4x6 cm sebanyak 2Lbr; e) surat penitipan senjata api.

\section{Upaya Polri dalam melakukan pengawasan penggunaan senjata api legal di wilayah hukum Kepolisian Daerah Metro Jaya}

Adapun upaya Polri dalam melakukan pengawasan penggunaan senjata api legal di wilayah hukum Polda Metro Jaya, adalah sebagaimana dijelaskan di bawah.

\section{Semua pemilik senpi harus lulus syarat serta serangkaian tes dari Intelkam Polda Metro Jaya}

Syarat-syarat kepemilikan senjata api, pemohon izin kepemilikan senjata api juga harus memenuhi syarat medis dan psikologis tertentu. Secara medis, pemohon harus sehat jasmani, tidak cacat fisik yang dapat mengurangi ketrampilan membawa dan menggunakan senjata api dan berpenglihatan normal. Syarat-syarat lain bisa saja ditetapkan oleh dokter umum/spesialis. Syarat lain, harus menyerahkan 
Surat Keterangan Kelakuan Baik (SKKB). Sementara itu, untuk syarat psikologis, pemohon harus orang yang tidak cepat gugup dan panik, tidak emosional dan tidak cepat marah serta yang paling utama pemohon juga bukan seorang yang memiliki kecenderungan psikopat. Pemenuhan syarat ini harus dibuktikan dengan hasil psikotes yang dilaksanakan oleh tim yang ditunjuk Dinas Psikologi Mabes Polri.

\section{Melakukan pengecekan fisik senjata api pada saat mengajukan perpanjangan izin}

Sebelumnya, pengawas berkewajiban untuk melakukan tes fisik senjata lama ataupun baru, ini semua demi keamanan dan keselamatan pengguna. Hal ini juga disampaikan oleh narasumber sebagai berikut:

"Melakukan cek fisik senpi juga sangat diperlukan dan wajib. Ini karena jika fisik senjata tidak layak, maka akan mempengaruhi pengguna dan keamanan lainnya"

Dari pernyataan di atas dapat diartikan bahwa selain cek dan syarat khusus kepada pemilik, tes atau cek juga dilakukan pada fisik senjata api, baik yang baru maupun senjata dari pemilik yang hendak melakukan perpanjangan izin kepemilikan. Pernyataan sebelumnya juga didukung oleh narasumber Briptu HA, jabatan anggota pengguna Senjata Api Legal, sebagai berikut:

"Cek fisik biasanya dilakukan pada senpi yang baru maupun yang sudah pernah digunakan oleh pengguna yang sedang dalam proses perpanjangan izin kepemilikan"

Dari pernyataan di atas, maka dapat dilihat bahwa senjata api yang akan digunakan oleh pemilik harus dicek secara fisik. Pada umumnya cek fisik meliputi daya pegas, uji balistik, dan kode atau nomor daftar senjata api. Hal ini disampaikan oleh narasumber Brigadir EJ, jabatan Bagian Yanmin Ditintelkam Polda Metro Jaya sebagai berikut:

\footnotetext{
"Pemeriksaan diberlakukan terhadap siapa saja yang memegang senpi. Ini juga merupakan penegakan disiplin serta pengawasan. Pemeriksaan meliputi kelengkapan administrasi, apakah surat-suratnya masih berlaku atau sudah mati. Selain itu, juga kondisi fisik senpi di antaranya peluru dan kebersihan senjata"
}

Dari pernyataan di atas, dapat diartikan bahwa pemeriksaan diberlakukan terhadap siapa saja yang memegang senjata api. Ini juga merupakan penegakan disiplin serta pengawasan. Pemeriksaan meliputi kelengkapan administrasi, apakah surat-suratnya masih berlaku atau sudah mati. Selain itu, juga kondisi fisik senpi di antaranya peluru dan kebersihan senjata api.

\section{Mengirimkan surat teguran kepada pemilik senjata api yang telah habis perizinan}

Perpanjangan kepemilikan senjata api harus segara dilaporkan, karena ini menyangkut prosedur hukum yang berkaitan dengan keselamatan dan keamanan diri dan orang banyak. Kepemilikan senjata api, memiliki batas waktu yang ditentukan, jika masa perizinan telah habis maka diwajibkan untuk memperpanjang kembali. Hal ini untuk menjaga keamanan dan kestabilan pemilik senjata api legal di Indonesia.

Jika masih ditemukan pemilik senjata api yang lalai dalam melakukan perpanjangan secara tepat waktu saat masa izin telah habis maka hukuman dapat dikenakan pada pemilik atau pengguna senjata api tersebut. Hal ini mengacu pada Perkap Polri Nomor 8 Tahun 2012, Pasal 40 huruf (c) menjelaskan bahwa pemilik senjata api berkewajiban untuk memperpanjang izin senjata api yang akan habis masa berlakunya.

\section{Memberikan sosialisasi yang berkesinambungan kepada pemilik senjata api}

Dari waktu ke waktu kepemilikan senjata api terus meningkat baik secara kualitatif maupun secara kuantitatif. Secara kuantitatif karena jumlah kepemilikan senjata api semakin banyak di samping peredarannya yang semakin meluas. Hal ini diungkapkan oleh narasumber Kombes Pol. M, jabatan 
Direktur Intelkam Polda Metro Jaya, sebagai berikut:

"Pemilik senjata api legal di Indonesia sudah meningkat pesat, dari kebutuhan personil TNI/Polri maupun yang lembaga lain dan masyarakat sipil. Jadi ini perlu sosialisasi yang berkesinambungan mengenai keamanan penggunaan senjata api tersebut."

Berdasarkan hal tersebut, Polri menilai sosialisasi berkesinambungan dibutuhkan mengenai keamanan penggunaan senjata api. Kegiatan sosialisasi dalam upaya keamanan dan pengawasan kepemilikan senjata api yang dilakukan oleh Polda Metro Jaya terhadap pemilik senjata api telah dilaksanakan dengan berbagai upaya teknik komunikasi diantaranya dengan melakukan serangkaian kegiatan yang terjadwal secara rutin dan tes psikologis saat permohonan kepemilikan senjata api.

\section{Penyitaan senjata api apabila terbukti melakukan pelanggaran}

Jika pemilik senjata api yang diizinkan oleh Polda Metro Jaya melakukan pelanggaranterhadap kepemilikan senjata api, maka akan dilakukan penyitaan dan pemilik senjata api tersebut akan dimintai keterangan.

\section{Studi kasus perizinan penggunaan senjata api legal di wilayah hukum Kepolisian Daerah Metro Jaya}

Jika pemohon merupakan masyarakat sipil yang ingin menggunakan senjata api, maka tujuan dan manfaat senjata api adalah masuk dalam kategori bela diri. Penguasaan senjata api yang diberikan peraturan kepada masyarakat sipil tentunya harus dengan batasan-batasan yang berlaku. Penggunaan senjata api oleh sipil antara lain untuk kepentingan tertentu seperti olahraga menembak dan/atau berburu, serta sebagai koleksi (Hikmawati 2012).

Berbeda dengan warga sipil, dalam rangka menjaga keutuhan wilayah Negara Kesatuan Republik Indonesia, diperlukan perlengkapan untuk menunjangnya yang ditugaskan pada anggota militer. Pada prinsipnya sesuai dengan perlengkapan standar militer, maka setiap prajurit militer dilengkapi dengan senjata api. Namun, dalam kondisi non tempur/non operasi maka pembawaan senjata api dilakukan pembatasan untuk menghindari penyalahgunaan.

Prajurit yang diperbolehkan membawa senjata pada saat non-tempur adalah mereka yang bertugas khusus seperti latihan, petugas jaga, staf intelijen/pengamanan. Para komandan satuan dan tugas-tugas pengamanan. Sedangkan, untuk satuan- satuan tempur hanya perwira yang diperbolehkan membawa senjata api. Sementara untuk polisi, peraturan yang mengatur mengenai penggunaan senjata api oleh polisi antara lain diatur dalam Perkapolri No. 8 Tahun 2009 tentang Implementasi Prinsip dan Standar Hak Asasi Manusia dalam Penyelenggaraan Tugas Kepolisian Negara Republik Indonesia, serta di dalam Perkapolri No. 1 tahun 2009 tentang Penggunaan Kekuatan dalam Tindakan Kepolisian. Berdasarkan Pasal 47 Perkapolri No. 8 Tahun 2009 disebutkan bahwa: 1) Penggunaan senjata api hanya boleh digunakan bila benar- benar diperuntukkan untuk melindungi nyawa manusia; 2) Senjata api bagi petugas hanya boleh digunakan untuk: a) dalam hal menghadapi keadaan luar biasa; b) membela diri dari ancaman kematian dan/atau luka berat; c) membela orang lain terhadap ancaman kematian dan/atau luka berat; d) mencegah terjadinya kejahatan berat atau yang mengancam jiwa orang; e) menahan, mencegah atau menghentikan seseorang yang sedang atau akan melakukan tindakan yang sangat membahayakan jiwa; dan f) menangani situasi yang membahayakan jiwa, dimana langkah-langkah yang lebih lunak tidak cukup.

\section{Simpulan}

Penggunaan senjata api legal di bawah perizinan Kepolisian Daerah Metro Jaya yaitu perizinan impor senjata api, perizinan hibah, perizinan kepemilikan baru, perizinan mutasi, perizinan perpanjangan kepemilikan dan perizinan pembaharuan buku pemilik senjata api. Upaya polri dalam melakukan pengawasan penggunaan senjata api legal di wilayah hukum Kepolisian Daerah Metro Jaya dengan cara 
semua pemilik senpi harus lulus syarat serta serangkaian tes baik fisik maupun kelengkapan dokumen persyaratan. Polda Metro Jaya juga memberlakukan sanksi atau hukuman untuk pemilik senjata api yang terbukti melakukan pelanggaran dalam penggunaan senjata api.

Penelitian ini memberikan saran yakni dengan memperketat pengawasan data pribadi pengguna senjata api legal termasuk alamat domisili dengan melakukan pembaharuan data setiap pelaksanaan perpanjangan izin kepemilikan; menambah jumlah personil khususnya anggota khusus Ditintelkam yang mahir dibidang persenjataan; meningkatkan sosialisasi informal dengan bantuan anggota perbankin (Persatuan Menembak Sasaran dan Berburu Indonesia).

\section{Daftar Pustaka}

Bangalore S \& Franz HM (2013) Gun ownership and firearm-related deaths. The American Journal of Medicine 126 (10): 873-876.

Grassel KM, Wintemute GJ, Wright MA \& Romero MP (2003) Association between handgun purchase and mortality from firearm injury. Injury Prevention 9:48-52.

Handoko TH (2001) Manajemen Personalia dan Sumber Daya Manusia. Yogyakarta: Haji Masagung.

Hasibuan \& Malayu SP (2001) Manajemen Sumber Daya Manusia. Jakarta: Bumi Aksara.

Hikmawati P (2012) Kontroversi kepemilikan senjata api oleh warga sipil. Info Hukum 4 (10):1-4.

Karp A (2011) Estimating civilian owned firearms. Small Arms Survey Research Notes 9:1-4.

Latifah M (2017) Kepemilikan dan penyalahgunaan senjata api di Indonesia. Info Hukum 9 (22):1-4.

Lott JR (1998) More Guns Less Crime. Understanding Crime and Gun Control Laws. Chicago: University of Chicago Press.

Peraturan Kepala Kepolisian Negara Republik Indonesia Nomor 1 Tahun 2009 Tentang Penggunaan Kekuatan dalam Tindakan Kepolisian.

Peraturan Kepala Kepolisian Negara Republik Indonesia Nomor 8 Tahun 2009 Tentang Implementasi Prinsip dan Standar Hak Asasi Manusia dalam Penyelenggaraan Tugas Kepolisian Negara Republik Indonesia.

Peraturan Kepala Kepolisian Negara Republik Indonesia Nomor 8 Tahun 2012 Tentang Pengawasan dan Pengendalian Senjata Api Untuk Kepentingan Olahraga.

Peraturan Pemerintah Pengganti Undang-Undang Nomor 20 Tahun 1960 Tentang Kewenangan Perizinan yang diberikan Menurut Perundang-Undangan Mengenai Senjata Api.

Siagian SP (1982) Administrasi Pembangunan. Jakarta: Gunung Agung.

Smith TW (2001) National gun policy survey of the national opinion research centre: Research findings. Chicago: University of Chicago, National Opinion Research Center.

Terry GR (2006) Prinsip-Prinsip Manajemen. Jakarta: Bumi Aksara.

Undang-Undang Darurat Republik Indonesia Nomor 12 Tahun 1951 Lembaran Negara Nomor 78 Tahun 1951 tentang Senjata Api.

Undang-Undang Republik Indonesia Nomor 8 Tahun 1948 tentang Pendaftaran Dan Pemberian Izin Pemakaian Senjata Api.

Undang-Undang Republik Indonesia Nomor 2 Tahun 2002 Tentang Kepolisian Negara Republik Indonesia.

Yusman HE (2015) Pengawasan dan pengendalian senjata yang beredar di masyarakat (kajian paradigma normatif dan interpretatif dalam kriminologi). e-Jurnal Katalogis 3 (12):89-95. 